\title{
Geological and geochemical variations in Mid-Tertiary Ethiopian Flood Basalt Province, Maychew, Tigray Region, Ethiopia
}

\section{Kurkura Kabeto*}

Department of Earth Science, College of Natural and Computational Sciences, P.O. Box 231, Mekelle University, Ethiopia (*kurkura57@yahoo.com)

\begin{abstract}
The paper presents the results of a comprehensive major element, trace element, and Sr-Nd-PbHf isotopic study of Mid-Tertiary volcanic sequences from the northwestern flood basalt province in Ethiopia. The volcanic rocks studied range in composition from basanites, alkaline basalts, and ankaramites, which form the 1st three sequences at the base associated with basaltic agglomerate (sequence 1, 2 and 3) to transitional and tholeiitic basalts and picrites confined to the upper three sequences (sequences 4, 5 and 6). Sequence 5 is bimodal with intermediate-felsic pyroclastic rocks intercalating the transitional-tholeiitic basalts. There is a good correlation of sequences with geochemical enrichments, such as an increase $\mathrm{La} / \mathrm{Lu}_{\mathrm{N}}$ with $\mathrm{TiO}_{2}$, and decrease in $\mathrm{Al}_{2} \mathrm{O}_{3}$ and $\mathrm{SiO}_{2}$ towards the base. The smooth increase of $\mathrm{La} / \mathrm{Lu}_{\mathrm{N}}$ ratios in lower sequences reflect the general decrease of degree of partial melting that sampled heterogeneous packages of mantle plume materials. In the $\mathrm{Sr}-\mathrm{Nd}$ isotopic diagram two clusters are formed one with restricted and low- Sr- (0.70356-0.70345) and Nd- (0.51290-0.51284) isotopic compositions, defined by sequence 1 , and the other cluster with relatively higher ${ }^{87} \mathrm{Sr} /{ }^{86} \mathrm{Sr}(0.7052-0.7036)$ and ${ }^{143} \mathrm{Nd} /{ }^{144} \mathrm{Nd}(0.51296-0.5127)$ isotopic compositions defined by samples from sequence 2 , and most other sequences with little scatter. The $\mathrm{Pb}$-isotopic compositions vary systematically within each sequence (from base to top), and each sequence clustered systematically in a different $\mathrm{Pb}-$ $\mathrm{Pb}$ - isotopic space with the highest ${ }^{206} \mathrm{~Pb} /{ }^{204} \mathrm{~Pb}(19.10-19.30)$ and ${ }^{207} \mathrm{~Pb} /{ }^{204} \mathrm{~Pb}(15.60-15.65)$ measured in sequence 1, quite differently from other sequences and from previously reported for northwestern Ethiopian flood basalt province, and the lowest ${ }^{206} \mathrm{~Pb} /{ }^{204} \mathrm{~Pb}(18.20-18.56)$ and ${ }^{207} \mathrm{~Pb} /{ }^{204} \mathrm{~Pb}$ (15.51-15.55) measured in sequence 4. Sequence 2 and 3 lavas display a similar ${ }^{206} \mathrm{~Pb} /{ }^{204} \mathrm{~Pb}$ and ${ }^{207} \mathrm{~Pb} /{ }^{204} \mathrm{~Pb}$ ranges falling between sequence 1 and 4 . In contrast, sequence 6 samples displayed towards higher ${ }^{206} \mathrm{~Pb} /{ }^{204} \mathrm{~Pb}$ than sequence 2, 3, and 4, but with lower and higher ${ }^{207} \mathrm{~Pb} /{ }^{204} \mathrm{~Pb}$ than sequence 1 and 5 respectively. The lavas of sequence 1 and 4 have relatively less radiogenic ${ }^{176} \mathrm{Hf} /{ }^{177} \mathrm{Hf}$ than other sequences with slight scatter. The systematic geochemical variations in lavas are remarkable and reflects three mantle end component mixing with minimal crustal in put as a fourth component. The enriched sequence 1 has very similar geochemistry to HIMU-type ocean island basalts (OIBs), and this end member ascribed to be the most enriched Afar plume component 1, which is the most enriched Afar Plume component during initial continental break. The second enriched component is defined by sequence 2 and 3 samples and may reflect the second enriched component in Ethiopian flood basalt, previously reported for the high-Ti2 basalts assumed to be the enriched Afar Plume component, whereas the third component is the depleted component defined by sequence 4 partly overlap the range previously reported for low-Ti basalts.
\end{abstract}

Keywords: Flood basalts, Geochemistry, $\mathrm{Sr}-\mathrm{Nd}, \mathrm{Pb}-\mathrm{Pb}$, Hf-Hf isotopes, Afar Plume, Partial melting, Crustal input.

(C) CNCS

Mekelle University 


\section{INTRODUCTION}

The Mid-Tertiary ( 30 Ma) Ethiopian continental flood basalts form part of the larger AfroArabian Igneous Province, which is related to the Afar plume and the Red Sea-Gulf of Aden -

Ethiopian Rift triple junction. Maychew, the area, of present study (Fig. 1) forms part of the high-Ti basalts of Ethiopian flood basalt province. Rocks here are composed of alkaline lavas (basanites, basalts, and ankaramites, with basaltic agglomerate) at the base, felsic volcanics in the middle, and transitional to tholeiitic mafic lavas at the top of the transitional sequence. Pik et al. $(1998,1999)$ have classified the north-western Ethiopian flood basalts into three distinct geochemical groups based on trace element and Ti concentrations: low-Ti basalts (LT), high-Ti1 (HT1) basalts and high-Ti2 (HT2) basalts. They recognized a suite of 'low-Ti' (LT) basalts restricted to the northwestern part of the province (Fig. 1) assumed to be derived from depleted mantle. They are characterized by relatively flat REE patterns and lower Ti and incompatible trace element concentrations. Alkali basalts found to the south and east of the province on the other hand show higher concentrations of incompatible elements and more fractionated REE patterns and related to the so-called 'high-Ti' basalts (HT1 and HT2).

In Western Ethiopian Plateau, up to $2 \mathrm{~km}$ thick predominantly mafic lavas with minor felsic pyroclastics (Fig. 1) make up the northern part of the Ethiopian flood basalt sequence (e.g., Hoffman, 1997; Ayalew et al., 2002) and cover an area of $\sim 106 \mathrm{~km}^{3}$ (Rochette et al., 1998). The Maychew area is located in the northern eastern corner of the western Ethiopian plateau and covers an area of about $100 \mathrm{~km}^{2}$. At present there is no geochronological data available for Maychew lavas to verify the sequential variations, but the earlier K-Ar whole-rock age dating of basalts collected from $110 \mathrm{~m}$ and $140 \mathrm{~m}$ above base in Maychew area gave 26.2 Ma and 25.7 Ma (Jones, 1976), respectively. However, such a young age compared to the current refined and accepted mineral ${ }^{40} \mathrm{Ar} /{ }^{39} \mathrm{Ar}$ age of 30.9 and 29.2 Ma for the northwestern Ethiopian continental flood lavas (Hofmann et al., 1997; Coulie et al., 2003; Kieffer et al., 2004) could be related to the unrecognized argon loss or gain in these intensely weathered formations. Hence, at present 31-29 $\mathrm{Ma}$ is accepted as a reasonable estimate for the Maychew flood basalt sequence. As shown in figure 1, the Maychew area is located between the Adigrat area and Chinese road section (A and C, in Fig. 1) and the samples collected from these areas are dated between 31-29 Ma. Moreover, recently Kieffer et al. (2004), dated plagioclase separate from alkaline picrite from Bora (C) CNCS 
Mountain (B in Fig. 1, close to Maychew area) at $30.99 \pm 0.13 \mathrm{Ma}$. The dated sample is taken from lateral variation of ankaramite/ picrite of sequence 2 (Fig. 2). The younger age of $29.2 \mathrm{Ma}$ (Hofmann et al., 1997) is obtained from ignimbrite layers exposed at the topper part of the sequences, which is equivalent to sequence 5 described at Maychew area.

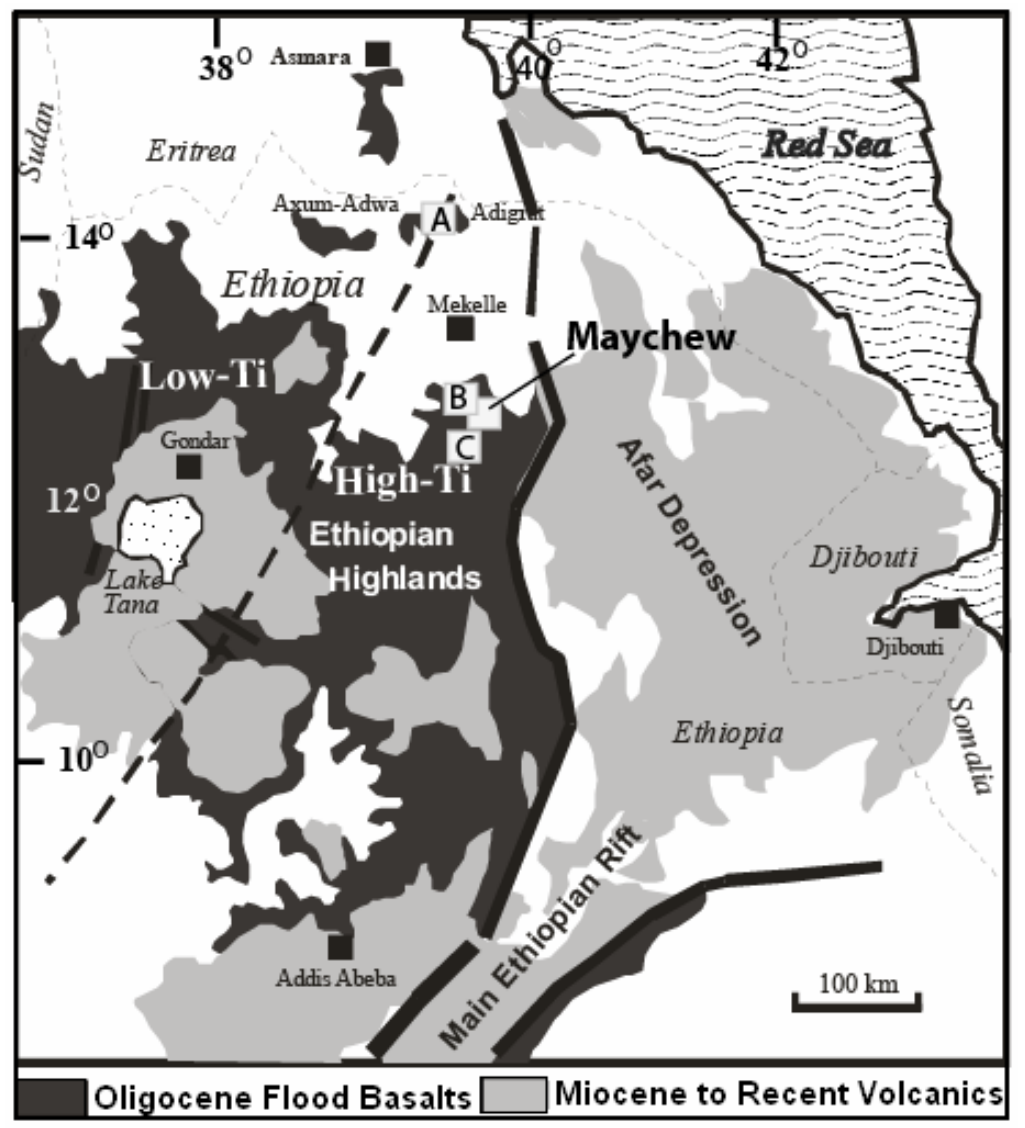

Figure 1. Location map of NW Ethiopian Plateau, Afar Rift and Main Ethiopian Rift (from Kuster et al., 2005). The approximate broken line separates the low-Ti and High-Ti flood basalt province (Pik et al., 1998).

Despite a relatively large chemical database for the southern and western Ethiopian plateau volcanics, there are still many parts of the plateau magmatism that are not studied. Most studies on Ethiopian rift and plateau magmatism have been carried out at a regional scale (Pik et al., 1999, Kieffer et al., 2004), and detailed investigations on single sections of the plateau are scarce. Moreover, lack of a detailed geological map of any particular section of the Ethiopian flood basalt province makes it difficult to correlate much of the existing high quality geochemical data from various parts of the Ethiopian flood basalt province. This paper presents (C) CNCS 
geology map of part Maychew area dominated by high-Ti basalts (Figs.1; 2 \& 3). Systematic rock sampling of selected sections was carried out. They are analysed for whole-rock major and trace elements, $\mathrm{Sr}, \mathrm{Nd}, \mathrm{Pb}$, and $\mathrm{Hf}$ isotopic data using suitable procedures (Nakamura et al., 2003) at Pheasant Memorial Laboratory of the Institute for study the earth's Interior, Okayama University at Misasa. The large data set of the volcanics thus obtained is discussed in the paper in addition to geology and stratigraphic sequence of the flows.

\section{STRATIGRAPHIC SEQUENCES, PETROGRAPHIC DESCRIPTION OF VOLCANICS OF MAYCHEW AREA}

Geology of Maychew area covered in this paper includes many lithological units (Figs. $2 \&$ 3) and the volcanic successions which reveal six cycles (referred as sequence, Kabeto et al., 2004). Out of six, four are related to mafic-agglomerate volcanism (exposed between 1800-2900 m a.s.l, sequences 1,2,3, and 4), in which basanites, and alkaline basalts and transitional ankaramites occupy the base (sequences 1,2 and 3) followed by silica rich tholeiitic to transitional sequence 4. This is followed by sequence 5 of mafic-felsic volcanism $(2900-3450 \mathrm{~m})$ and that is covered by tholeiitic to transitional basalts of sequence $6(3450-3780 \mathrm{~m})$; and represent the last stage of flood basalt volcanism in the Eastern part of northwestern Ethiopian plateau flood basalts. The lower most mafic sequence (Sequence 1) is in fault contact with Cretaceous Amba Aradam Sandstone, indicating that the base of the sequence is not exposed (Figs. $2 \& 3$ ). The sequences lack major unconformities; although intercalations of 10-20 cm thick paleosols are common in some sequences otherwise volcanism and depositions were continuous (Fig. 3). The lower three sequences $(1,2 \& 3)$ are more disturbed and tilted at $4-25^{\circ}$ towards SE than upper 3 sequences (4, 5 \& 6). However, along NNE-SSW, NNW-SSE, and ENE-WSW striking normal faults they are also weakly tilted at about $3-4^{\circ}$, and disturbed. The altitude sub-division used above may vary depending on these normal faults throw, which is clear at Bekura and Tsibet mountains (Figs. 2 \& 3). There is evidence of deformation of the type that Merla (1979) and Brehe et al. (1987) used to differentiate the deformed lower and upper undeformed formations, however, such evidence was not observed in the northwestern part of the plateau (Kieffer et al., 2004).

In Maychew area, there is a marked change in the morphology. Sequence 1, 2, and 3 are marked by deformed and subdued topography. However, sequence 2 also display gently undulating (c) CNCS 
morphology and the steepness of the slope is passing from sequence 2 to 3 and the first sharp cliff marks sequence 4 . The exposure of sequence 5 is marked by broken flat surface where the andesitic pyroclastics nearly eroded to flat surface (suitable agricultural land) and a resistant pediment made up of picrite and ankaramite. 2 sharp cliffs one in the middle and the other on top is marked by 15 to $10 \mathrm{~m}$ thick consolidated tuff and ignimbrite partly showing columnar joints. The last sequence forms tabular facies, in which flow units are about $12 \mathrm{~m}$ thick, alternate with braided lobes of pahoehe of $\sim 1$ to $3 \mathrm{~m}$ thick. The sequence 2 and 3 resemble the high-Ti2 and the other sequences $\left(4,5\right.$, and 6) might be considered as high- $\mathrm{TiO}_{2} 1$ of Pik et al. $(1998,1999)$. However, sequence 1 is described for the first time in the Ethiopian Plateau Geology (Kabeto et al., 2004, 2006). There is systematic variation in the characteristics of the dominant volcanic rocks from the base (1800 m, Mehoni plain) of the Maychew volcanic sequence to the summit at the Tsibet Mountain (3780 m) (Figs. 2 \& 3) and these sequences are described below.

2.1. Sequence 1: Deeply weathered and often tilted basanite and basaltic agglomerate intercalations ( between 1800 and $2500 \mathrm{~m}$ ). Sequence 1 ranges in maximum thickness from 100$150 \mathrm{~m}$ and mark the base of exposed flood basalt province (at Mehoni plain and at the base of Bekura Mt.), and comprise many individual flows. Typically occur as a series of stacked flows 2$6 \mathrm{~m}$ thick separated at places by paleosol horizons $(5-20 \mathrm{~cm})$. Basanitic agglomerate layers are also common. The massive flows contain very few microphenocrysts $(<2 \%)$ of greenish elongated clinopyroxene (diopsidic) and Fe-Ti oxides with rare olivine mostly altered, in the groundmass of clinopyroxene, phlogophite, opaque, glass and rare plagioclase.

2.2. Sequence 2: It ranges in thickness from $450-600 \mathrm{~m}(\sim 2000-2500 \mathrm{~m})$ and comprise many individual flows. It is strongly weathered and tilted. The alkaline basalt and ankaramite flows typically occur as a series of stacked flows 1-10 m thick separated commonly by patchy basaltic agglomerate (1-10 $\mathrm{m})$ layers. The mafic lava flows of this sequence consist of four litho-types, ankaramite, aphanitic basalts, porphyritic basalts and basaltic agglomerates. Porphyritic basalts and ankaramite predominates and often contain phenocryst (10-80\%) of greenish and brownish clinopyroxene (zoned) and olivine, which are commonly iddingsitised. Fe-Ti oxides, plagioclase, clinopyroxene and glass form the microphenocryst and groundmass phases. Few ankaramites contain abundant olivine phenocryst compared to clinopyroxene. The aphanitic flows are generally microcrystalline with few pyroxenes and altered olivine microphenocrysts and often (c) CNCS

Mekelle University 
form the base and top of the sequence.

2.3. Sequence 3: It consists of ankaramite, phyric basalts and agglomerate intercalations ( 2500 $2700 \mathrm{~m}$ ) and ranges in thickness from 150-200 m. It comprises many individual massive cumulative ankaramites and porphyritic basalts (Fig. 3). The lavas typically occur as a series of massive to blocky bodies of 30-40 m thick separated by patchy agglomerate $(\sim 2 \mathrm{~m})$ and phyric basalt $(2-3 \mathrm{~m})$ layers. The ankaramites range in composition from pyroxene-rich at base to plagioclase-rich in the top and olivine gabbros at the middle that form intergranular/gabbroic texture consisting of dominantly Ti-augite (3-6 mm), followed by plagioclase (2-3 $\mathrm{mm})$, olivine and Fe-Ti oxides (1-2 mm), forming seriate texture. The top part of sequence 3 is plagioclase dominant basalt.

2.4. Sequence 4: Cliff forming aphyric to phyric basalts and basaltic agglomerate intercalations ( 2700-2900 m), and has a maximum thickness of $200 \mathrm{~m}$ (Fig. 2). The transitional to tholeiitic basaltic flows typically comprise many horizontally stratified flows of 1-5 m thick separated by patchy basaltic agglomerate $(0.5-1 \mathrm{~m})$. The lava flows consist of three litho-types, aphanitic, and slightly porphyritic basalts, and basaltic agglomerate. Flows in this sequence typically contain up to $10 \%$ plagioclase phenocryst in a pilotaxitic groundmass of predominantly plagioclase microlites, pyroxene, and Fe-Ti oxides and glass now altered partly to chlorite and epidote. Trachytic texture is common, and few samples contain microphenocryst of brownish clinopyroxene, Fe-Ti oxides, and olivine.

2.5. Sequence 5: The sequence marks the bimodal volcanic activity in the northwestern Ethiopian flood basalt province ( $2900-3450 \mathrm{~m})$. The pyroclastic rocks consist of two lithotypes: greenish to yellowish-grey andesitic tephera and grey trachy-rhyolitic ignimbrite. Greenish to grey varieties form the basal part of the pyroclastic flow deposits, whereas welded variety form the top part even grading to thinly banded rhyolite $(20-35 \mathrm{~cm})$ flows at the top of the ignimbrite layers (Fig. 2). In between the basal andesitic tephera and the top ignimbrite and rhyolite flows, phyric to aphyric basalts and picrite-ankaramite occur (Fig. 2). Greenish andesitic tephera variety predominates and they form crystal, rock, and glass fragments in glassy rarely devitrified and epidotized groundmass. The crystals are commonly plagioclase, aegirine-augite, and opaques possibly Fe-Ti oxides. In the ignimbrites, aegirine-augite and abundant sanidine with few opaque and anorthoclase, and rare rock fragments together form the fragmental part. 
Variably weathered and partly welded glassy ash forms the groundmass. Olivine rich ankaramite show intergranular texture consists of dominantly olivine, clinopyroxene, and plagioclase. Samples taken from Aygi section is commonly olivine picrites, where olivine predominates over clinopyroxene and plagioclase, whereas from Tsibet mountain section (Figs. 2 \& 3), clinopyroxene and plagioclase predominate over olivine and at places range to olivine gabbro composition similar to sequence 3 ankaramites.

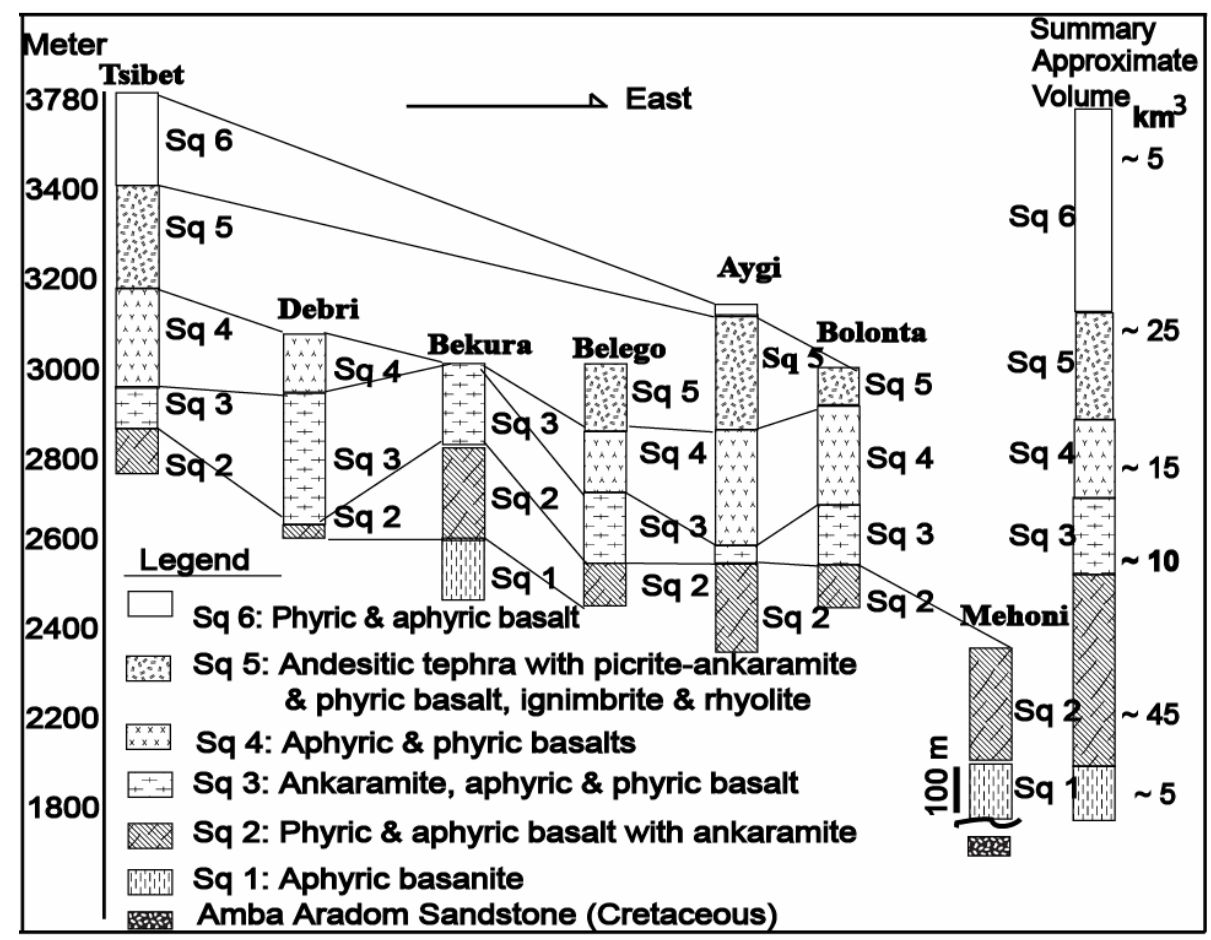

Figure 2. Schematic columnar section of Maychew area (modified from Kabeto et al., 2004). Numbers on the left side are elevations in meter above sea level. Abbreviation: Sq1 = Sequencel. The scale on the right of lithological column is in hundreds of meters.

2.6. Sequence 6: The upper part of the flood basalt sequences in Maychew area is marked by unimodal, $330 \mathrm{~m}$ thick transitional to tholeiitic basalt of sequence $6(3450-3780 \mathrm{~m})$, and comprise many series of horizontally stratified massive to blocky jointed 5-10 m thick lava sequence. Porphyritic basalts which predominate the sequence consist of plagioclase (up to 20\%) forming commonly glomeroporphyritic clots with rare clinopyroxene, olivine, and microphenocrysts of $\mathrm{Fe}-\mathrm{Ti}$ oxides in the pilotaxitic groundmass of plagioclase, opaque, clinopyroxene, and glass. The groundmass in some thin sections is altered to chlorite. In rare (C) CNCS 
case olivine (3-5 $\mathrm{mm})$ also form the dominant phenocryst phase.

The petrographic study of Maychew mafic lavas show systematic phenocryst assemblage variations starting from base to top, where at the base very few microphenocrysts of clinopyroxene characterizes sequence 1 (basanite). The predominance of clinopyroxene phenocryst with appearance of olivine in most samples typifies sequence 2. Sequence 3 is characterized by appearance of plagioclase and predominance of clinopyroxene and olivine (ankaramite), whereas plagioclase predominate the phenocryst phase in sequence 4. Olivine predominates the phenocryst phase over plagioclase and pyroxene in sequence 5; and plagioclase

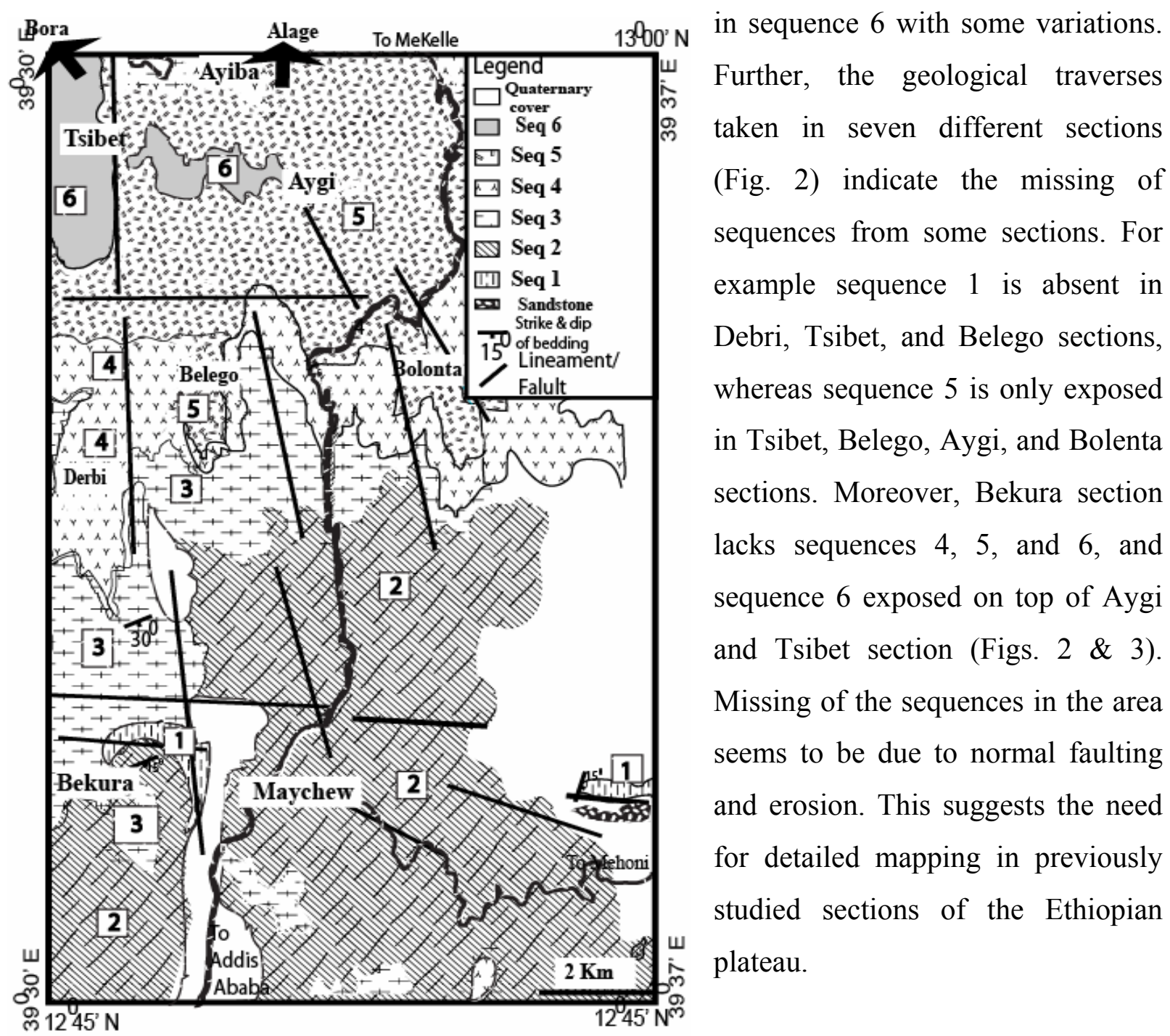

Figure 3. Geological map of Maychew area (Numbers on the map indicate sequences as shown in Figure 2. Bora is $20 \mathrm{Km} \mathrm{NW}$ and Alage is $20 \mathrm{Km}$ north of the map area). 


\section{SAMPLING STRATEGY AND ANALYTICAL METHODS}

Geological mapping activity and samples of all possible fresh volcanic rocks exposed within the study area were collected during three separate field seasons. Seven different transects were selected within $100 \mathrm{~km}^{2}$, to enable detail mapping, and sampling a wide, a diversity of temporal and spatial chemical variations as possible in a high-Ti zone of the flood basalt sequence.

The samples were analyzed for whole-rock major and trace elements, and Sr-, Nd-, Pb-, and Hfisotopic data at the Pheasant Memorial Laboratory (PML), Institute for study the earth's Interior, Okayama University at Misasa. A total of 89 whole-rock samples were crushed using jaw crusher to coarse chips of 3-5 mm size, from which fresh chips were carefully hand-picked. They were rinsed with deionized water in an ultrasonic bath at least three times, and then they were dried at $100^{\circ} \mathrm{C}$ for 12 hours. The washed and dried chips were ground using an alumina puck mill. Major elements, $\mathrm{Ni}$ and $\mathrm{Cr}$ data were obtained using $\mathrm{X}$-ray fluorescence spectrometer (XRF) (Phillips PW2400) on glass beads containing a lithium tetraborate flux (10 to 1 dilution of samples) (Takei, 2002). Loss on ignition (LOI) was obtained gravimetrically. Trace elements were determined by isotope dilution (ID) and analyzed by inductively coupled plasma mass spectrometry (ICP-MS) using a Agilents $7500 \mathrm{cs}$ system fitted with a flow injection system (Makishima \& Nakamura, 1997; Makishima et al., 1997, 1999; Yokoyama et al., 1999; Moriguti et al., 2004). Isotopes data for $\mathrm{Rb}, \mathrm{Sr}, \mathrm{Sm}$ and $\mathrm{Nd}$ were generated for the samples selected for $\mathrm{Sr}-$ $\mathrm{Nd}$ isotopic measurement, by isotope dilution thermal ionization mass spectrometry using a modified Finningan MAT261 instrument with NBS983 standard. Trace element concentrations in $\mathrm{CaO}$ - rich samples were measured by the Al-addition methods as suggested by Tanaka et al. (2007 \& reference therein). All of the major and trace elements analyses were duplicated for each sample, and replicate analyses had $<0.5$ relative $\%$ and 3-5 relative $\%$ difference, for major and trace elements, respectively.

The analytical procedures for chemical separation and mass spectrometry followed in the study are from Yoshikawa \& Nakamura (1993) for Sr isotope measurements; Makishima \& Nakamura (1991) for Nd; Kuritani \& Nakamura (2002) for Pb; and Lu et al. (2007) for Hf. To remove the effect of secondary alterations (after petrographic examinations) all powders for $\mathrm{Pb}$ - and $\mathrm{Hf}$ - and some samples for Sr-Nd- isotopic measurements were leached with $6 \mathrm{~N} \mathrm{HCl}$ at $70^{\circ} \mathrm{C}$ for about 9 hours, before acid digestions.

(c) CNCS 
Mass spectrometry was carried out with TIMS system in static multi-collection mode. Normalizing factors to correct isotopic fractionation during spectrometer analysis are ${ }^{86} \mathrm{Sr} /{ }^{88} \mathrm{Sr}=$ 0.1194 for $\mathrm{Sr}$ and ${ }^{146} \mathrm{Nd} /{ }^{144} \mathrm{Nd}=0.7219$ for $\mathrm{Nd}$. The isotopic composition of NIST SRM987 and LaJolla standards are ${ }^{87} \mathrm{Sr} /{ }^{86} \mathrm{Sr}=0.710190$ and ${ }^{143} \mathrm{Nd} /{ }^{144} \mathrm{Nd}=0.511863$, respectively (Makishima $\&$ Masuda, 1993) and are reported relative to long-term (over 2 years) laboratory averages. For $\mathrm{Pb}$ isotope measurements the correction of mass fractionation was carried out by the normal double spike method using a ${ }^{207} \mathrm{~Pb}^{-204} \mathrm{~Pb}$ spike, as described by Kuritani \& Nakamura (2003). The isotopic composition of NIST SRM981 Pb standard gave an average $(\mathrm{n}=5)$ of ${ }^{206} \mathrm{~Pb} /{ }^{204} \mathrm{~Pb}=$

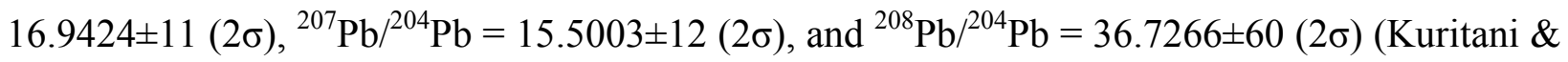
Nakamura, 2003). ${ }^{176} \mathrm{Hf} /{ }^{177} \mathrm{Hf}$ of the JMC475 and JMC14374 Hf standards yield averages of $0.282150 \pm 6(2 \sigma, \mathrm{n}=9)$ and $0.282187 \pm 8(2 \sigma, \mathrm{n}=13)$, respectively during the course of analysis. All Hf (Makishima et al., 1999) isotope data for the samples are, however, reported relative to ${ }^{176} \mathrm{Hf} /{ }^{177} \mathrm{Hf}$ of the $\mathrm{JMC} 475=0.282160$.

\section{RESULTS AND DISCUSSION}

\subsection{Classification of the volcanic flows/sequences}

According to the total alkali- $\mathrm{SiO}_{2}$ classification diagram (Fig. 4), mafic rock types range in composition from basanite, picrite-ankaramite, basalt to basalt-trachy-andesite. But transitional to sub-alkaline basalts predominate. In contrast with many continental flood basalts, the mafic rocks at Maychew area do not entirely show tholeiitic affinities and also do not fall in the basalt field (Fig. 4). Based on the petrographic data and lithological assemblages the different mafic lavas are subdivided in to six sequences from base to top. General characteristics of the mafic rocks are illustrated in the total alkalis-silica (TAS) diagram (Fig. 4).

The Maychew sequences have compositions that plot, with some exceptions, in the alkaline and sub-alkaline field, respectively. According to the proposed classification of Ethiopian flood basalts (Piccerillo et al., 1979), the sequences 1 and 2 are alkaline in composition, whereas sequences 3 and 4 lavas have compositions that plot between alkaline (few) and sub-alkaline field, indicating transitional character. However, the sequence 4 shows higher $\mathrm{SiO}_{2}$ contents and/or higher $\mathrm{Na}_{2} \mathrm{O}+\mathrm{K}_{2} \mathrm{O}$ (up to 5.2 wt.\%) contents and some samples plot in the alkali field when compared to sequence 5 and 6 samples, which have lower $\mathrm{SiO}_{2}$ and $\mathrm{Na}_{2} \mathrm{O}+\mathrm{K}_{2} \mathrm{O}(<3.5$ (c) CNCS 
wt.\%) and plotted towards tholeiitic field line. These distinctions extend to other incompatible major and trace elements. In this study three samples from sequence 2, twelve samples from sequence 3, and five samples from sequence 5 are plotted in picrite field, having $\mathrm{MgO}$ contents $>$ 12 wt.\% and total alkalis $<3$ wt.\% (Fig. 4), as per IUGS classification (Le Bas, 2000). However, as per petrographic data these samples (picrite) since dominant in clinopyroxene, are assigned as ankaramitic picrites, whereas samples with olivine dominant as picrites.

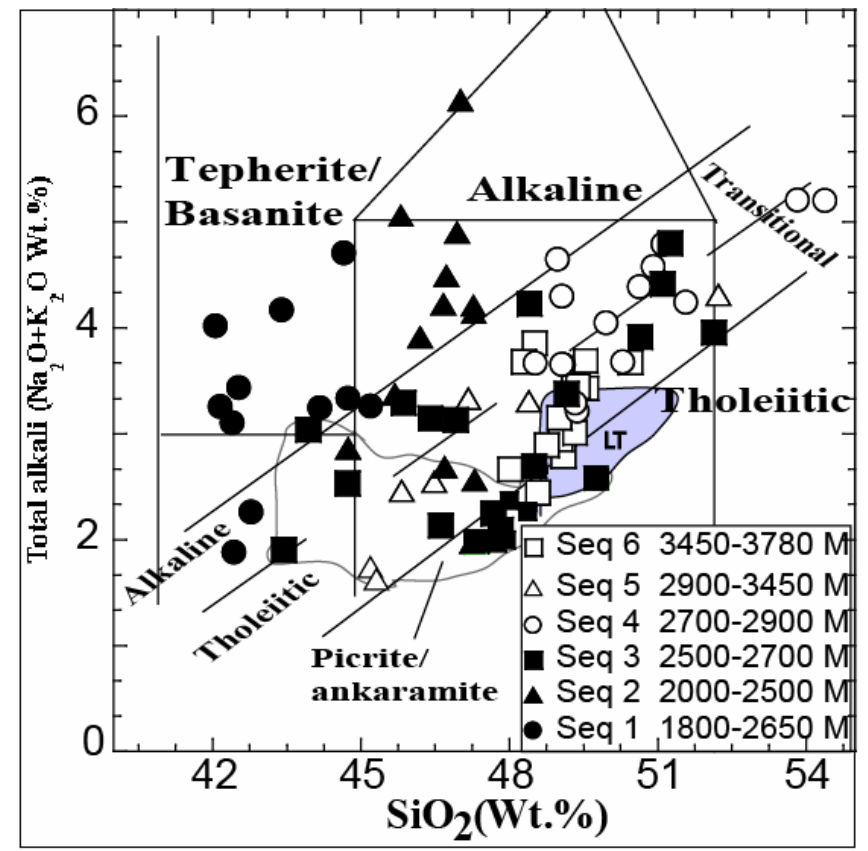

Figure 4. Total alkali Silica Classification of Maychew lavas compared with the low-Ti (LT) basalts (Pik et al., 1998).

The low-Ti basalts (LT shaded, Fig.4) (Pik et al., 1998; Kieffer et al., 2004) are compared with Maychew lavas.

\subsection{Major element compositions of mafic rocks from the Maychew flood basalt section}

General characteristics of the mafic rocks are illustrated in the total alkalis-silica (TAS) diagram (Fig. 4), and plots of the selected major and trace elements versus $\mathrm{MgO}$ shown in figure 5. The lavas from sequence 1 and 2 are referred as basanites because with two or three exceptions majority samples plot in the alkaline field. On the other hand, the lavas from sequences 3 and 4 are referred to as transitional ankaramite and basalt respectively as they plot in the transitional 
field and from sequences 5 and 6 are referred to as tholeiitic picrites-ankaramite and basalts as they plot though within the transitional field but towards tholeiitic affinity. The Maychew lava sequences can be broadly grouped from base to top as strongly alkaline, transitional, and tholeiitic and these subdivisions also well reflected in major oxides, trace element, and Sr-, Nd-, $\mathrm{Pb}-$, and $\mathrm{Hf}$ - isotopic compositional variations. The mafic lavas span a large range in $\mathrm{MgO}$, from primitive $(\sim 23 \mathrm{Wt} . \%)$ to evolved ( 4 Wt. \%) compositions. In general, the ankaramites and picrites from sequences 3 and 5 show highest $\mathrm{MgO}$ content and the transitional basalts of sequence 4 the lowest. Sequence 3 displays a wide variation in $\mathrm{MgO}$ content followed by sequences 5 and 2 . $\mathrm{SiO}_{2}$ content (Figs. $4 \& 5$ ) for the Maychew mafic lavas ranges from 42 to 54 Wt. \%, basanites $<45$ Wt.\% (Seq.1) and transitional basalts $>48$ Wt.\% (Seq.4). $\mathrm{SiO}_{2}, \mathrm{Al}_{2} \mathrm{O}_{3}$, $\mathrm{TiO}_{2}$, and $\mathrm{K}_{2} \mathrm{O}$ (not shown) contents display broad negative correlations with $\mathrm{MgO}$, whereas $\mathrm{CaO}$ content in sequences 2, 3 and 5 shows initial negative correlation with $\mathrm{MgO}$ till the content reached $12 \mathrm{Wt} . \%$, afterwards the correlation becomes positive. Sequences 1, 4 and 6 (if $\mathrm{MgO}$ rich sample is excluded) on the other hand display positive correlation compared to others indicating their differentiated nature. Basanite (Seq.1) shows significant compositional difference than other sequences i.e. lowest in $\mathrm{SiO}_{2}$ and $\mathrm{Al}_{2} \mathrm{O}_{3}$, highest in $\mathrm{FeO}_{\text {total }}, \mathrm{CaO}$ and $\mathrm{MnO}$ (not shown) contents. Further, alkaline basalt of sequence 2, also shows lower values for $\mathrm{SiO}_{2}$ and $\mathrm{Al}_{2} \mathrm{O}_{3}$ than the sequences upwards, but display higher $\mathrm{FeO}_{\text {total }}$ and $\mathrm{TiO}_{2}$ contents. On the contrary, sequences 5 and 6 show lower values for $\mathrm{TiO}_{2}$ and the highest for $\mathrm{Al}_{2} \mathrm{O}_{3}$ with few exceptions that overlap sequences 4 and $3 . \mathrm{K}_{2} \mathrm{O}$ content is variable in most sequences, it is relatively higher in sequence 3 than sequence 4 at a given $\mathrm{MgO}$ content except with few overlap. Similar difference can be inferred from contents of $\mathrm{CaO}$ and $\mathrm{TiO}_{2}$. Major element chemical variations within each sequence can be largely explained by crystal fractionation involving olivine, clinopyroxene, iron-titanium oxides, and plagioclase, however, difference in $\mathrm{TiO}_{2}, \mathrm{CaO}$, $\mathrm{K}_{2} \mathrm{O}, \mathrm{Al}_{2} \mathrm{O}_{3}$ and to some extent in $\mathrm{SiO}_{2}$ and $\mathrm{FeO}_{\text {total }}$ among the six sequences reflect source variations or/and variable degrees of partial melting.

In figure 5, major element vs. $\mathrm{MgO}$, majority elements clearly show existence of compositional variations among sequences. However, in some cases there is an overlap e.g. sequence 3 and 2 overlap in more mafic compositions, but their evolved varieties differ in $\mathrm{TiO}_{2}, \mathrm{FeO}_{\text {total }}, \mathrm{Al}_{2} \mathrm{O}_{3}$, and $\mathrm{SiO}_{2}$ content. Similarly, the sequences 3 and 4 indicate overlap in their evolved varieties in (C) CNCS 
$\mathrm{MgO}$ vs. $\mathrm{Al}_{2} \mathrm{O}_{3}, \mathrm{SiO}_{2}, \mathrm{FeO}_{\text {total }}$ and $\mathrm{TiO}_{2}$, but they do differ in $\mathrm{K}_{2} \mathrm{O}$ and $\mathrm{CaO}$ contents (Fig. 5d).

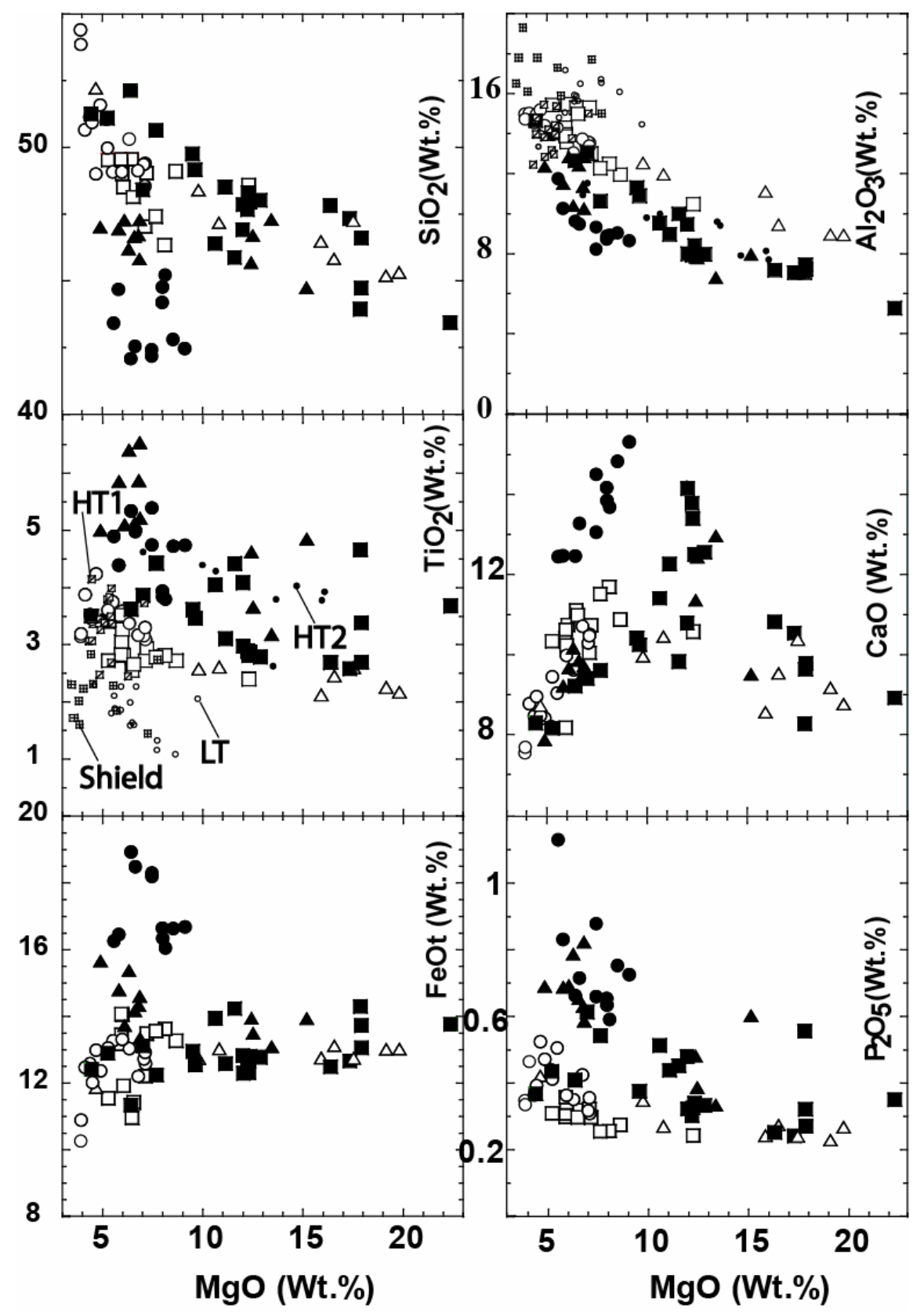

Figure 5. MgO vs. selected major oxides for Maychew lavas. LT, HT1, and HT2 and Shield basalts are taken from Pik et al. (1998); and Kieffer et al. (2004).

The notable compositional variation in $\mathrm{SiO}_{2}, \mathrm{Al}_{2} \mathrm{O}_{3}, \mathrm{TiO} 2, \mathrm{P}_{2} \mathrm{O}_{5}, \mathrm{FeO}_{\text {total }}$, and $\mathrm{CaO}$ among the lavas will further demonstrate the existence of rather six sequences $(1,2,3,4,5$, and 6$)$.

(C) CNCS 

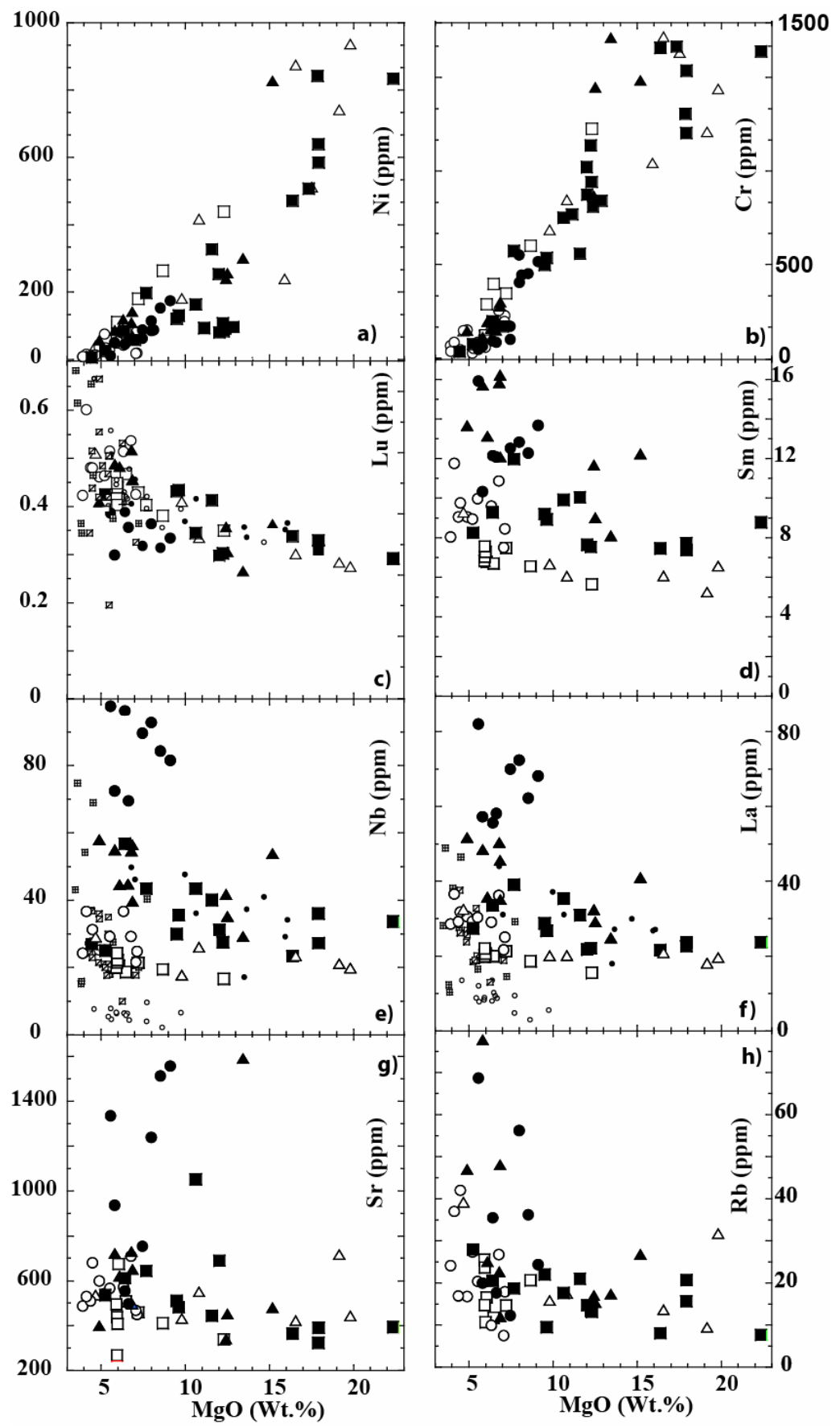

Figure 6. $\mathrm{MgO}$ vs. selected trace elements for Maychew lavas. The HT1 (small crossed rectangle), HT2 (shaded dots) and LT (small open circle) basalts are shown for comparison on c, e \& f. HT2 overlaps fields of sequence $2 \& 3$, HT1 overlaps fields of evolved sequence 3, Sequence 4, 5 and 6, whereas LT basalts do not overlap any of Maychew sequences (when incompatible elements such as $\mathrm{Nb} \&$ La are considered).

(C) CNCS 
The sequence 1 and 2 show the greatest relative enrichment in $\mathrm{P}_{2} \mathrm{O}_{5}, \mathrm{FeO}_{\text {total }}$ and $\mathrm{TiO}_{5}$. In contrast, the upper sequences $3,4,5$, and 6 shows relatively low $\mathrm{P}_{2} \mathrm{O}_{5}, \mathrm{FeO}_{\text {total }}$, and $\mathrm{TiO}_{2}$, but highly enriched in $\mathrm{SiO}_{2}$ and $\mathrm{Al}_{2} \mathrm{O}_{3}$. Between 1 \& 2, sequencel shows lower $\mathrm{SiO}_{2}$ (45-42 Wt. \%), $\mathrm{Al}_{2} \mathrm{O}_{3}$ (12-8.5 Wt.\%) and $\mathrm{TiO}_{2}(5.4-3.6 \mathrm{Wt} . \%)$ and higher $\mathrm{CaO}(15-12 \mathrm{Wt} . \%)$ and $\mathrm{FeO}_{\text {total }}$ (18.216 Wt.\%) (Figs. 4 \& 5). Compared to 4, sequence 3 shows higher $\mathrm{P}_{2} \mathrm{O}_{5}, \mathrm{~K}_{2} \mathrm{O}$ and $\mathrm{TiO}_{2}$ and lower $\mathrm{Al}_{2} \mathrm{O}_{3}$ and $\mathrm{CaO}$ than, however, their $\mathrm{SiO}_{2}, \mathrm{Na}_{2} \mathrm{O}$ (not shown) and $\mathrm{FeO}_{\text {total }}$ concentrations appear equally variable and scattered in both sequences. Moreover, $\mathrm{CaO}$ concentrations in sequence 4 lavas are higher than that of sequences 3 and 2 lavas with respect to $\mathrm{MgO}$ content. In the case of $\mathrm{Na}_{2} \mathrm{O}$ and $\mathrm{K}_{2} \mathrm{O}$, they are scattered considerably in all the sequences and suggest secondary redistribution of $\mathrm{Na}$ and $\mathrm{K}$. However, the extent of secondary alteration has also been evaluated using $\mathrm{K}_{2} \mathrm{O} / \mathrm{P}_{2} \mathrm{O}_{5}$, which is $>1$ (not shown) in all types except for the three basanite samples from sequence 1 , indicating minimum influence of subaerial weathering. $\mathrm{K}_{2} \mathrm{O} / \mathrm{P}_{2} \mathrm{O}_{5}$ ratio is used in evaluating the effect of subaerial weathering in mafic lavas, where $\mathrm{K}$ is easily leached by secondary alteration and $\mathrm{P}$ is not.

\subsection{Trace element compositions of mafic rocks from the Maychew flood basalt section}

The compatible elements $\mathrm{Ni}$ and $\mathrm{Cr}$ (Fig. 6a \& b) show perfect linear relationship with $\mathrm{MgO}$ and suggest the control of olivine, clinopyroxene, and $\mathrm{Cr}$-spinel. Presence of olivine, clinopyroxene or/and $\mathrm{Cr}$-spinel well explains high contents of $\mathrm{MgO}, \mathrm{Ni}$, and $\mathrm{Cr}$ in picrite and ankaramite (Seq. $5,3 \& 2$ ). They are possibly mantle-derived melts having $\sim 11 \% \mathrm{MgO}$ (Skovgaard et al., 2001). Crystal fractionation is the preferred mechanism for $\mathrm{Cr}$ depletion as its abundance is not expected to vary under conditions of increasing partial melting (Pearce and Norry, 1979). The incompatible elements $\mathrm{La}, \mathrm{Nb}, \mathrm{Lu}, \mathrm{Sm}, \mathrm{Sr}$ and $\mathrm{Rb}$ (Figs. 6c, d, e, h \& f) with some scatter increase with decreasing MgO. The basanites (Seq.1) at the base of Maychew flood basalt section has the highest relative enrichments of incompatible trace elements ( $\mathrm{La} \& \mathrm{Nb}$ ). The sequence 2, alkaline basalts and ankaramites, has intermediate contents and in the upper sequence 3, 4, 5 and 6 the trace elements sequentially depleted upwards with some scatter. Basanites display relatively fractionated rare earth element $(\mathrm{REE})$ patterns $\left((\mathrm{La} / \mathrm{Lu})_{\mathrm{N}}=30-18\right.$ (subscript $\mathrm{N}$ denotes chondrite normalization) compared to other sequences (Seq.2, $\mathrm{La} / \mathrm{Lu}_{\mathrm{N}}=16$ 9; Seq. 3, La/Lu $u_{N}=14-7$; Seq. 4, La/Lu $/ u_{N}=9-6$; Seq. 5, La/Lu $\operatorname{Lu}_{N}=10-6$; Seq. 6, La/Lu ${ }_{N}=7-5$ ) (Fig. 7d). So, there exist a good correlation of rock types with varying geochemical enrichments 
such as an increase in $(\mathrm{La} / \mathrm{Lu})_{\mathrm{N}}$ with $\mathrm{TiO}_{2}$ and a general decrease in $\mathrm{Al}_{2} \mathrm{O}_{3}$ and $\mathrm{SiO}_{2}$ towards the base (Figs. 6 \& 7).
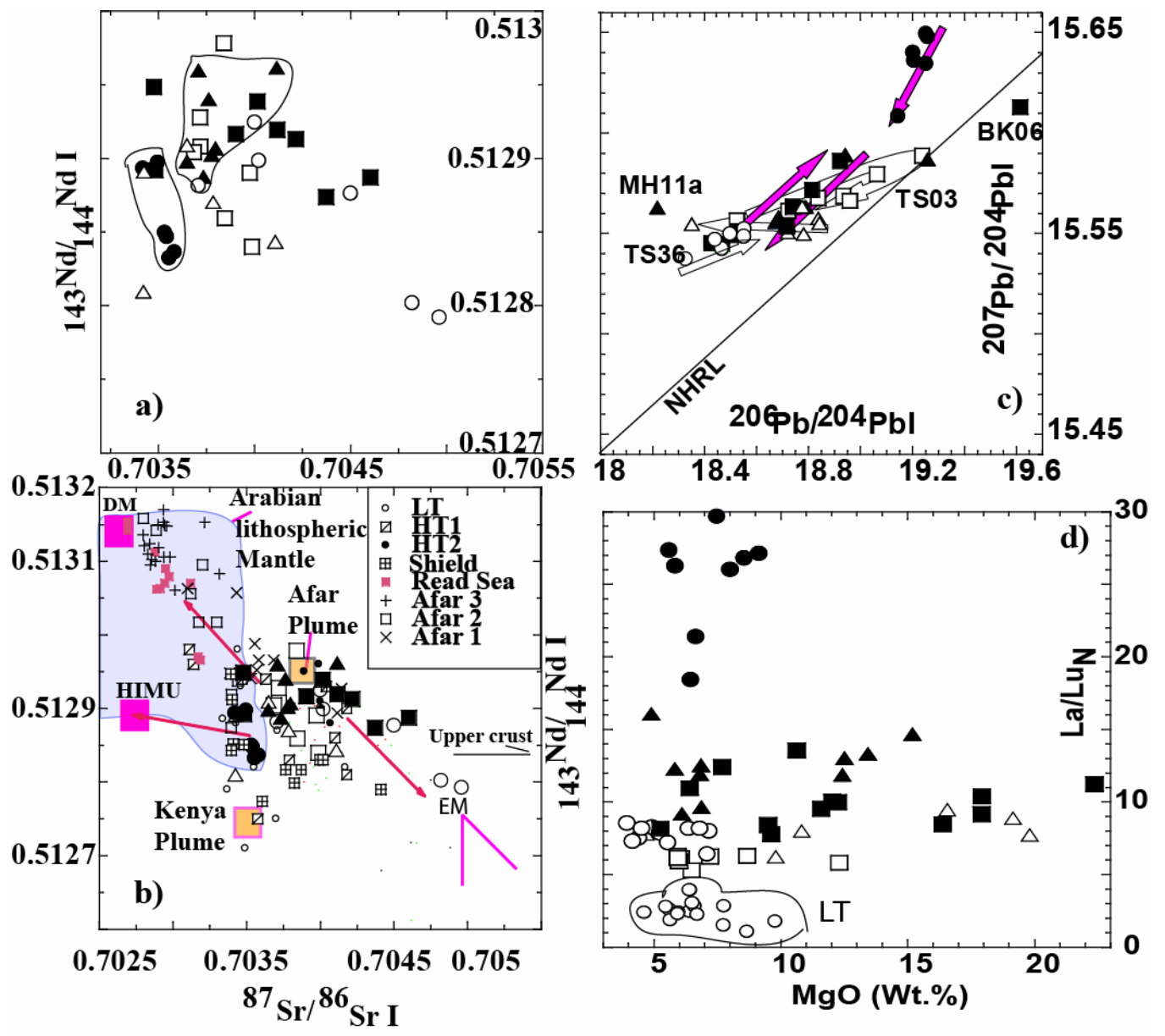

Figure 7. a). ${ }^{87} \mathrm{Sr} /{ }^{86} \mathrm{Sr}-{ }^{143} \mathrm{Nd} /{ }^{144} \mathrm{Nd}$ initial ratio plot, b). ${ }^{87} \mathrm{Sr} /{ }^{86} \mathrm{Sr}-{ }^{143} \mathrm{Nd} /{ }^{144} \mathrm{Nd}$ initial ratio plots comparing Maychew lavas with volcanics in the region, c). ${ }^{207} \mathrm{~Pb} /{ }^{204} \mathrm{~Pb}-{ }^{206} \mathrm{~Pb} /{ }^{204} \mathrm{~Pb}$, plot d) $\mathrm{MgO} \mathrm{Vs} \mathrm{La/Lu}$ plots for Ethiopian flood basalt section at Maychew [The data range for LT, HT1, \& HT2 is from Pik et al. (1999). Afar group data range is from Schilling et al. (1992). The Red Sea data is from Vidal et al. (1991). Arrows in c mimics way up. Note: in b, DM- Depleted mantle; HIMU- high- $\mu$; EM- Enriched mantle; in c, NHRL Northern-Hemisphere Reference-Line; BK-06, TS03; and MH11a are samples which plots differently from the sequence.

\subsection{Isotope variations}

Among the analyzed isotopes, Sr-Nd isotope data (Fig. 7 a \& b) when plotted, two clusters are formed, one with restricted and low $\mathrm{Sr}$ (0.70356-0.70345) and $\mathrm{Nd}$ (0.51290-0.51284) isotopic compositions, defined by sequence 1 samples, and the other cluster with relatively higher $\mathrm{Sr}$ (C) CNCS 
(0.7052-0.7036) and $\mathrm{Nd}(0.51296-0.5127)$, defined by sequence 2 . Other sequences show more scattered patterns.
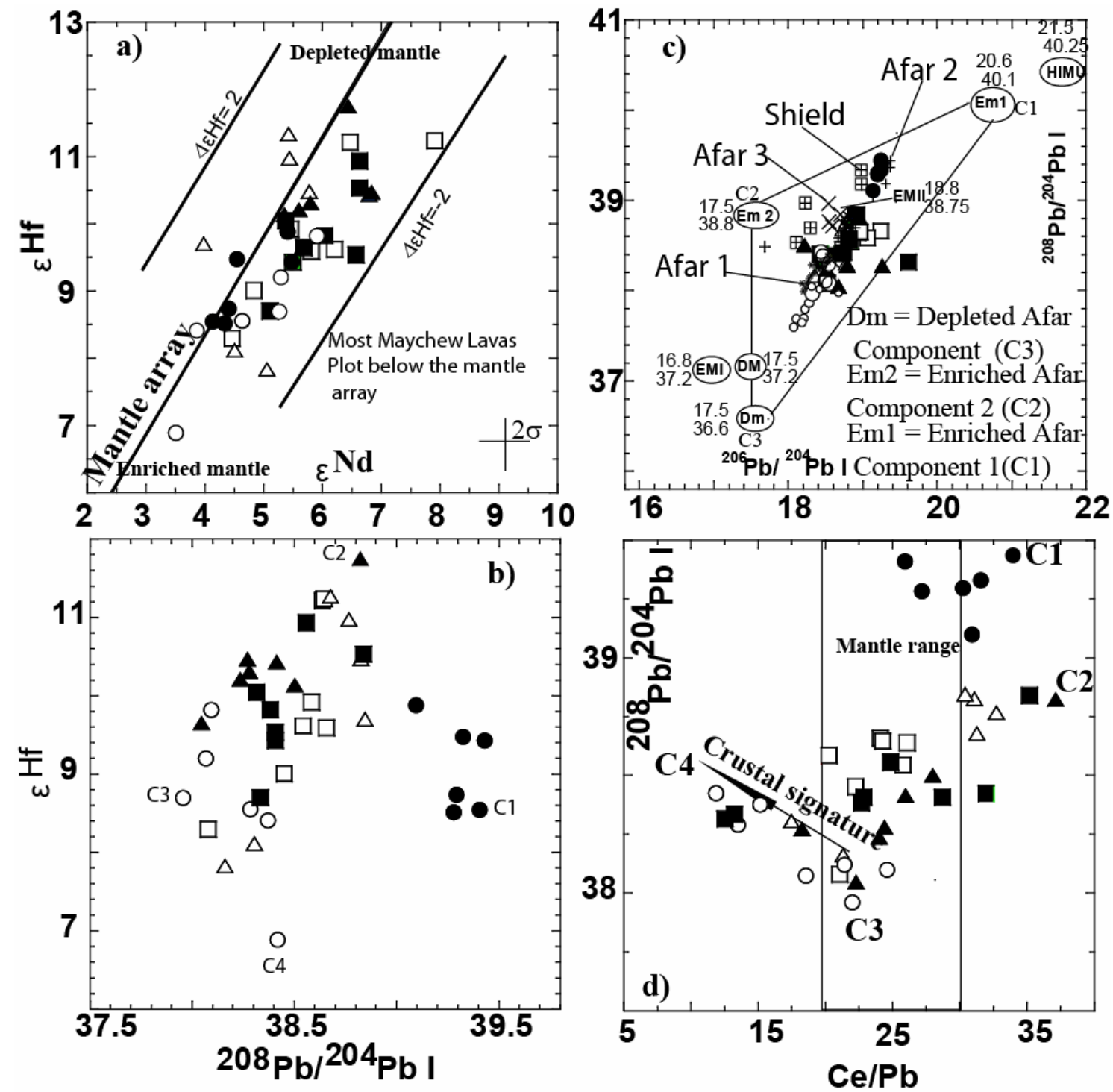

Figure 8. a). $\boldsymbol{\varepsilon H f - \varepsilon N d , ~ b ) . ~} \boldsymbol{\varepsilon} \mathrm{Hf} \mathrm{Vs}{ }^{208} \mathrm{~Pb} /{ }^{204} \mathrm{~Pb}$ initial, c). ${ }^{208} \mathrm{~Pb} /{ }^{204} \mathrm{~Pb} \mathrm{Vs}{ }^{206} \mathrm{~Pb} /{ }^{204} \mathrm{~Pb}$, and d). ${ }^{208} \mathrm{~Pb} /{ }^{204} \mathrm{~Pb} \mathrm{Vs} \mathrm{Ce} / \mathrm{Pb}$ plots for Maychew flood basalt samples. $\mathrm{C} 1, \mathrm{C} 2, \mathrm{C} 3$, and $\mathrm{C} 4 \mathrm{in} \mathrm{b}$, indicate mixing components defined by the Maychew lava sequence. The three Afar plume mantle end components further elucidated in Figure 8c where sequence 1 and 0 Ma Afar group 2 (Schilling et al., 1992) displaced towards the highest ${ }^{206} \mathrm{~Pb} /{ }^{204} \mathrm{~Pb}$ ratios. In Figure $8 \mathrm{~d}$ most samples are plotted within and above the proposed mantle range, however, some samples are (lower part of sequence 3 and upper part of sequence $4 \& 5$ ) are displaced towards C4, crustal component. Symbols for Maychew lavas are as in Figures $4 \& 7$. 
$\mathrm{Pb}$ isotopic compositions (Figs. 7c \& 8) also show a systematic variation from base to top, with sequence 1 having the most radiogenic signature $\left({ }^{206} \mathrm{~Pb} /{ }^{204} \mathrm{~Pb}=19.10-19.30,{ }^{207} \mathrm{~Pb} /{ }^{204} \mathrm{~Pb}=15.60\right.$ 15.65) while sequence 4 indicating lower values $\left({ }^{206} \mathrm{~Pb} /{ }^{204} \mathrm{~Pb}=18.20-18.56,{ }^{207} \mathrm{~Pb} /{ }^{204} \mathrm{~Pb}=15.51\right.$ 15.55). Sequences 2 and 3 lavas display similar ${ }^{206} \mathrm{~Pb} /{ }^{204} \mathrm{~Pb}$ and ${ }^{207} \mathrm{~Pb} /{ }^{204} \mathrm{~Pb}$ ratios. Sequence 6 samples on the other hand though show lower ${ }^{207} \mathrm{~Pb} /{ }^{204} \mathrm{~Pb}$ (Fig. 7c) values, they are higher ${ }^{206} \mathrm{~Pb} /{ }^{204} \mathrm{~Pb}$ than in the samples from sequences $2,3,4$ and 5. Similarly lavas of sequence 1 and 4 are relatively less radiogenic ${ }^{176} \mathrm{Hf} /{ }^{177} \mathrm{Hf}$ than sequence 2 (Fig. 8a). In other sequences the data show slight scattered pattern (Fig. 7c). These variations are quite different from what has previously been reported for northwestern Ethiopian flood basalt province (Pik et al., 1999).

\section{CONCLUSION}

- The HT1+HT2 zone of northwestern Ethiopian flood basalt province show sequential compositional variations (Seq 1-Seq 6). The sequence $2 \& 3$ are similar to HT2 of Pik et al (1998), whereas Sequence 4 overlaps the ranges of HT1 basalts of Pik et al (1998). Sequence 1, basanites is described for first time in this study and enriched in incompatible elements more than the HT2 basalts. Sequence 5 and 6 show different chemical variations in isotopic ratios than HT1 and HT2.

- Smooth increase of $(\mathrm{La} / \mathrm{Lu})_{\mathrm{N}}$ ratios down the sequence reflect the general decrease of degree of partial melting of heterogeneous packages of mantle materials.

- The systematic geochemical variations in lavas are interpreted to reflect mixing of three mantle components, with minimal crustal in-put as a fourth component.

- The enriched sequence 1 has very similar geochemistry to HIMU-type ocean island basalts, and this ascribed as end member to the most enriched Afar plume component 1 involved in the initial continental break-up.

- The second enriched component is defined on the basis of the geochemistry of the samples from sequences $2 \& 3$ which reflect the second enriched component in Ethiopian flood basalt, previously described (Pik et al., 1999) as high-Ti2 basalts assumed to be the Afar Plume component.

- The third component would be the depleted one as defined by samples from sequence 4 , (C) CNCS 
which partly overlaps the range previously reported for low-Ti basalts (Fig. 8; Pik et al., 1999).

- The difference between the $1^{\text {st }}$ and $2^{\text {nd }}$ enriched Afar Plume components might be due to variable lithospheric signatures, with the $2^{\text {nd }}$ enriched Afar plume component having more lithospheric material.

- The forth component is crustal signature (Fig. 8d) which invariably affected all the lava sequences. Crustal signatures are quite prominent in sequences $3 \& 4$ compared to others.

\section{ACKNOWLEDGEMENTS}

Kurkura Kabeto acknowledges financial support from Japanese Society for Promotion of Science (JSPS) and also by the program for the 'Center of Excellence for the 21st Century in Japan' to ISEI, Okayama University. I thank Prof. Talat Ahmad and Dr. K. Bheemalingeswara, and the editor Dr. Tadesse for their constructive comments on the manuscript.

\section{REFERENCES}

Ayalew D., Barrey, P., Marty, B., Reisberg, L., Yirgu, G \& Pik. R. 2002. Source, genesis, and timing of giant ignimbrite deposits associated with Ethiopian continental flood basalts. Geochemica et Cosmochimica Acta, 66: 1429-1448.

Berhe, S.M., Desta, B., Nicoletti, M \& Tefera, M. 1987. Geology, geochronology and geodynamic implications of the Cenozoic magmatic province in $\mathrm{W}$ and SE Ethiopia. J. Geol. Soc. London, 144: 213-226.

Coulie', E., Quidelleur, X., Gillot, P.Y., Courtillot, V., Lefevre, J.C \& Chiesa, S. 2003. Comparative $\mathrm{K}-\mathrm{Ar}$ and $\mathrm{Ar} / \mathrm{Ar}$ dating of Ethiopianand Yemenite Oligocene volcanism: implications for timing andduration of the Ethiopian traps. Earth and Planetary Science Letters, 206: 477-492.

Hofmann, C., Courtillot, V., Feraud, G., Rochette, P., Yirgu, G., Ketefo, E \& Pik, R. 1997. Timing of the Ethiopian flood basalt event and implications for plume birth and global Change. Nature, 389: 838-841.

Jones, P. 1976. Age of the lower flood basalts of the Ethiopian plateau. Nature, 261: 567-569. 
Kabeto, K., Tanaka, R., Makishima, A \& Nakamura, E. 2006. Geological and geochemical evidence for sequential compositional variations in Mid-Tertiary Ethiopian Flood Basalt Province: implications for the Afar Plume enriched component. $2^{\text {nd }}$ AASP Int. Symp. Cameroon Volcanic Line, East African Rift System, the underlying Mantle and Evolution of the African Continental Crust. Dar es Salaam, Tanzania, Extended Abstract, 1: 19-25.

Kabeto, K., Sawada, Y., Bussert, R \& Kuester, D. 2004. Geology and Geochemistry of Maychew Volcanics, northwester Ethiopian Plateau. International Conference on East African Rift system, Addis Ababa, Ethiopia. Extended Abstarct $1: 110-114$.

Kieffer, B., Arndt, N., Lapierre, H., Basitien, F., Bosch, D., Pecher, A., Yirgu, G., Ayalew, D., Weis, D., Gerram, D.A., Keller, F \& Meugniot, C. 2004. Flood and Shield Basalts from Ethiopia: Magmas from the African Superswell. J. Petrology, 45: 793-834.

Kuritani, T \& Nakamura, E. 2002. Precise isotope analysis of nanogram-level $\mathrm{Pb}$ for natural rock samples without use of double spikes. Chemical Geology, 186: 31-43

Kuritani, T \& Nakamura, E. 2003. Highly precise and accurate isotopic analysis of small amounts of $\mathrm{Pb}$ using ${ }^{205} \mathrm{~Pb} /{ }^{204} \mathrm{~Pb}$ and ${ }^{207} \mathrm{~Pb} /{ }^{204} \mathrm{~Pb}$, two double spikes. Journal of Analytical and Atomic Spectrometry, 18: 1464-1470.

Kuster, D., Dwivedi, S. B., Kabeto, K., Mehary, K \& Matheis, G. 2005. Petrogenetic reconnaissance investigation of mafic sills associated with flood basalts, Mekelle basin, northern Ethiopia: implication for Ni-Cu exploration. J. Geochemical Exploration, 85: 63 -79 .

Le Bas, M.J. 2000. IUGS reclassification of the high-Mg and picritic volcanic rocks. $J$. Petrology, 41: 1467-1470.

Lu,Y., Makishima, A \& Nakamura, E. 2007. Purification of Hf in silicate materials using extraction chromatographic resin, and its application to precise determination of ${ }^{176} \mathrm{Hf} /{ }^{177} \mathrm{Hf}$ by MC-ICPMS with ${ }^{179} \mathrm{Hf}$ spike. J. Analytical and Atomic Spectrometry, 22: 69-76, doi:10.1039/b610197f.

Makishima, A \& Masuda, A. 1993. Primordial Ce isotopic composition of the solar system. Chem. Geology, 106: 197-205.

Makishima, A \& Nakamura, E. 1991. Determination of major, minor and trace elements in silicate samples by ICP-QMS and ICP-SFMS applying isotope dilution-internal (C) CNCS 
standardization (ID-IS) and multi-stage internal standardisation. Geostandards and Geoanalytical Research, 30: 245-271.

Makishima, A \& Nakamura, E. 1997. Suppression of matrix effects in ICP-MS by high power operation of ICP: Application to precise determination of Rb, Sr, Y, Cs, Ba, REE, Pb, Th and $\mathrm{U}$ at ng g1 levels in milligram silicate samples. Geostandards Newsletter, 21: 307319.

Makishima, A., Nakamura, E \& Nakano, T. 1997. Determination of boron in silicate samples by direct aspiration of sample HF solutions into ICP-MS. Analytical Chemistry, 69: 37543759.

Makishima, A., Nakamura, E \& Nakano, T. 1999. Determination of zirconium, niobium, hafnium and tantalum at ng g-1 levels in geological materials by direct nebulization of sample HF solution into FI-ICP-MS. Geostandards Newsletter, 23: 7-20.

Merla, G. 1979. Explanation to the Geology map of Ethiopia and Somalia 1:2,000,000 Scale. Department of Geology and Paleon., University of Florence, Italy

Moriguti, T., Makishima, A \& Nakamura, E. 2004. Determination of lithium contents in silicates by isotope dilution ICP-MS and its evaluation by isotope dilution thermal ionization mass spectrometry. Geostandards and Geoanalytical Research, 28: 371-382

Nakamura, E., Makishima, A., Moriguti, T., Kobayashi, K., Sakaguchi, C., Yokoyama, T., Tanaka, R., Kuritani, T \& Takei, H. 2003. Comprehensive geochemical analysis of small amounts $(<100 \mathrm{mg})$ of extraterrestrial samples for the analytical competition related to the sample-return mission, MUSES-C. Institute of Space and Astronautical Science Report, SP16: 49-101.

Pearce, J. A \& Norry, M. J. 1979. Petrogenetic implications of Ti, Zr, Y, and Nb variations in volcanic rocks. Contributions to Mineralogy and Petrology, 69: 33-47.

Pik, R., Daniel, C., Coulon, C., Yirgu, G., Hofman, C \& Ayalew, D. 1998. The northwestern Ethiopian flood basalts: Classification and spatial distribution of magma types. $J$. Volcanol. Geotherm. Res., 81: 91-111.

Pik, R., Daniel, C., Coulon, C., Yirgu, G \& Marty, B. 1999. Isotopic and trace element signatures of Ethiopian flood basalts: Evidence for plume lithosphere interactions. Geochim. Cosmochim Acta, 63: 2263-2279. 
Piccirillo, E.M., Justin-Visentin, E., Zanettin, B., Jotron, J. K \& Treuil, M. 1979. Geodynamic evolution from plateau to rift: major and trace element geochemistry of the central eastern Ethiopian plateau volcanics. Neues Jahrbuch fur geologie un Palantologie, 258: 139-79.

Rochette, E, Tamrat, E., F6raud, G., Pik, R., Courtillot, V., Ketefo, E. 1998. Magnetostratigraphy and timing of the Oligocene Ethiopian traps. Earth and Planetary Science Letters, 164: 497-510.

Schilling, J.-G., Kingsley, R. H, Hanan, B.B \& McCully B.L. 1992. Nd-Sr-Pb isotopic variations along Gulf of Aden Evidence for Afar Plume \& lithosphere interaction. J. Geophys Res., 97: 10927-10966.

Skovgaard, A.C., Storey, M., Baker, J., Blusztajn, J \& Varet, J. 2001. Geochemistry of basalts from Manda Hararo, Ethiopia: LREE-depleted basalts in Central Afar. Lithos, 69, 1-13.

Tanaka, R., Makishima, A \& Nakamura, E. 2007. Hawaiian double volcanic chain triggered by an episodic involvement of recycled material: Constraints from temporal $\mathrm{Sr}-\mathrm{Nd}-\mathrm{Hf}-\mathrm{Pb}$ isotopic trend of the Loa-type volcanoes. Earth and Planetary Science Letters, 30: 450465.

Takei, H. 2002. Development of precise analytical techniques for major and trace element concentrations in rock samples and their applications to the Hishikari Gold Mine, southern Kyushu, Japan. PhD thesis, Okayama University, 164p.

Vidal, P., Deniel, C., Vellutini, P. J., Piguet, P., Coulon, C., Vincent, J \& Audin, J. 1991. Changes of mantle source in the course of a rift evolution. Geophysical Research Letters, 18: 1913-1916.

Yoshikawa, M \& Nakamura, E. 1993. Precise isotope determination of trace amounts of $\mathrm{Sr}$ in magnesium-rich samples. J. Mineralogist, Petrologist \& Economic Geologist, 88: 548561.

Yokoyama T., Makishima A \& Nakamura E. 1999. Evaluation of the coprecipitation of incompatible trace elements with fluoride during silicate rock dissolution by acid digestion. Chemical Geology, 157: 175-187. 